\title{
HUBUNGAN TINGKAT PENGETAHUAN TENTANG KESEHATAN REPRODUKSI DENGAN PERILAKU SEKSUAL BERISIKO PADA REMAJA DI SMK NEGERI 1 KUTALIMBARU
}

\author{
Jujuren br Sitepu \\ Jurusan Kebidanan Poltekkes Kemenkes Medan
}

\begin{abstract}
Everyone has experienced to be adolescence. At this period, it will experience achange process both biological and psychological. The change influenced by society, close friend and mass media. The level of this research is an level of result, related to physical prosperity, bouncing and contact social, not only face from disease or weakness in all matter of related to health reproduce, function and its process. Adolescent attitude in this research is an attitude which is done to avoid the sexual contagion. It is a disease which is resulted by free sexual that happened of adolescent. Therefore, sex education to adolescent how to take care the reproduction organ to be healthy. Venereal diseases have been recognized, but after found a new disease the term changed to be sexual of transmitted Disease (STD) or sexual sectional. This research is analytic descriptive with a cross sectional research. It means that the data are taken at the same time. This research is done on October 2013 in SMUN 1 Kutalimbaru. The population is student of class ,11,12,13 SMUN 1 Kutalimbaru amount 257 samples. The conclusion from this research is the result of this research is counted by $68 \%$ adolescent categorized as sex active, there is no relation meaning between levels of reproduction health of knowledge with the sexual contagion. From the statistical test with the level of mistake is a $5 \%(0,05)$ and $P$ value is 0,673 , so Ho is refused there is no relation meaning between adolescent attitudes with the sexual contagion, from the statistical test with the level of mistake is a $5 \%$ $(0,05)$ and $P$ value is 1000 , so Ho is refused.
\end{abstract}

Keywords: Reproduction health, risk sexual behavior

\section{PENDAHULUAN}

A. Latar Belakang

Undang-Undang No.23 Tahun 1992 mendefinisikan bahwa kesehatan adalah keadaan sejahtera dari badan, jiwa dan sosial yangmemungkinkan setiap orang hidup produktif secara sosial dan ekonomis.

Menurut WHO, kesehatan reproduksi adalah kesehatan yang sempurna fisik, mental, sosial dan lingkungan serta bukan semata mata terbebas dari penyakit/kecacatan dalam segala aspek yang berhubungan dengan sistem reproduksi, fungsi serta prosesnya (Melyana,2005). Dengan adanya pengertian kesehatan reproduksi menurut WHO dan UndangUndang Kesehatan maka kita harus menjaga segala sesuatu yang berhubungan dengan sistem reproduksi, fungsi serta prosesnya sehingga akan tercipta suatu perilaku seksual yang sehat.

Pemahaman masyarakat tentang seksualitas masih amat kurang sampai saat ini. Kurangnya pemahaman ini amat jelas yaitu dengan adanya berbagai ketidaktahuan yang ada di masyarakat tentang seksualitas yang seharusnya dipahaminya. Sebagian dari masyarakat masih amat percaya pada mitos - mitos yang merupakan salah satu pemahaman yang salah tentang seksual.
Pemahaman tentang perilaku seksual remaja merupakan salah satu hal yang penting diketahui sebab masa remaja merupakan masa peralihan dari perilaku seksual anak anak menjadi perilaku seksual dewasa. Remaja mempunyai sifat yang unik, salah-satunya salah satunya adalah sifat ingin meniru sesuatu hal yang dilihat, kepada keadaan, serta lingkungan di sekitarnya. Disamping itu remaja mempunyai kebutuhan akan kesehatan seksual, dimana kebutuhan kesehatan seksual tersebut sangat bervariasi.(Kusmiran,2011)

Sebagian kelompok remaja mengalami kebingungan untuk memahami tentang apa yang boleh dilakukan dan apa yang tidak boleh dilakukan olehnya, antara lain boleh atau tidaknya melakukan pacaran, melakukan onani/mastrubasi nonton bersama atau ciuman. Ada beberapa kenyataan-kenyataan lain yang cukup membingungkan antara apasaja yang boleh dilakukan dan apa yang tidak boleh dilakukan. Kebingungan ini akan menimbulkan suatu perilaku seksual yang kurang sehat di kalangan remaja. Perasaan atau berdosa tidak jarang dialami oleh kelompok remaja yang pernah melakukan onani dalam hidupnya. Hal ini di akibatkan adanya pemahaman tentang ilmu pengetahuan yang di pertentangkan dengan pemahaman agama, yang sebenarnya harus saling menyokong. (Soetjiningsih,2010) 
Perkembangan ini akan berlangsung mulai sekitar 12 sampai 20 tahun.Kurangnya pemahaman tersebut disebabkan oleh berbagai faktor antara lain adat istiadat, budaya, agama, dan kurangnya informasi dari sumber yang benar. Hal ini akan mengakibatkan berbagai dampak yang justru amat merugikan kelompok remaja dan keluarganya (Soetjiningsih, 2010).

Data Badan Pusat statistik tahun 2013, didapat jumlah penduduk Indonesia 237 juta jiwa dari jumlah penduduk tersebut didapat jumlah remaja 62 juta jiwa dan $92 \%$ pelajar itu sudah melakukan kissing, petting dan oral sex, $62 \%$ pernah melakukan hubungan intim, $22.7 \%$ siswi SMA pernah melakukan aborsi.(Soetjiningsih, 2010).

Bila tidak disadari dengan pengetahuan yang cukup, mencoba hal baru yang berhubungan dengan kesehatan reproduksi bisa memberikan dampak yang akan menghancurkan masa depan remaja dan keluarga. (Tarwoto,2010)

Komisi Perlindungan Anak Indonesia mendapatkan hasil yang mencengangkan setelah melakukan penelitian di 17 kota besar di Indonesia pada termasuk Sumatera Utara pada tahun 2008 di temui dari 4.726 responden siswa SMP dan SMA ebanyak 62,7\% remaja SMP tidak perawan dan $21,2 \%$ remaja mengaku pernah aborsi. Perilaku seks bebas pada remaja tersebar di kota dan desa pada tingkat ekonomi kaya dan miskin.

Data BKKBN menunjukan pada tahun 2010 di JABODETABEK, remaja yang hilang keperawanannya mencapai $51 \%$. Remaja perempuan yang kegadisannya sudah hilang: Surabaya 54\%, Medan 52\%, Bandung 47\%, Yogyakarta 37\%.

Masturbasi atau onani merupakan salah satu aktivitas yang sering dilakukan oleh para remaja. Dari laporan penelitian yang dilaporkan oleh SIECUS ( Sex Information and Education Council of the United States ) menunjukkan bahwa $88 \%$ remaja laki - laki pada umur 16 tahun melakukan masturbasi dan remaja perempuan sebanyak $62 \%$. Frekuensinya makin meningkat sampai pada masa sesudah pubertas. Mereka mempunyai daya tarik seksual terhadap lawan jenis yang sebaya. Masturbasi ini dilakukan sendiri - sendiri dan juga dilakukan secara mutual dengan teman sebaya sejenis kelamin, tetapi sebagian dari mereka juga melakukan masturbasi secara mutual dengan pacar (Soetjiningsih, 2010).

Berdasarkan hasil studi pendahuluan yang telah dilakukan didapatkan data bahwa dari kelas 10,11 dan kelas 12 SMU Negeri 1Kutalimbaru memiliki remaja akhir (usia 15-20 tahun) 574 siswa, tergolong berperilaku baik akan tetapi ada beberapa remaja yang perilaku seksualnya dapat dikatakan buruk. Hal tersebut disebabkan oleh beberapa faktor yaitu status ekonomi yang rendah, pengetahuan tentang kesehatan reproduksi yang kurang, pengaruh penyebaran rangsangan seksual (pornografi) melaluimedia massa seperti VCD, telpon genggam, internet dan lingkungan pergaulan yang buruk sehingga karakter remaja dibentuk oleh lingkungan sekitarnya.

\section{METODE PENELITIAN}

A. Waktu dan Tempat Penelitian

Penelitian ini dilakukan pada tanggal 4 September - 14 September 2013. Sedangkan tempat penelitiannya di.SMUN I Kutalimbaru.

B. Populasi dan sample

1. Populasi

Populasi adalah keseluruhan subjek peneliti (Arikunto, 2006). Populasi dalam penelitian ini adalah siswa sebanyak 574 di SMUN Negeri 1 Kutalimbaru. Dari jumlah populasi tersebut diperoleh sample sebanyak 257 siswa, dengan kriteria inklusi remaja yang berusia $14-24$ tahun dan tercatat aktif sebagai siswa di SMU Negeri 1 Kutalimbaru dan tinggal di daerah atau desa kutalimbaru.

2. Sampel

Pengambilan sample dengan berstrata, proporsional dan acak (stratified proportional random sampling dari kelas 1 sebanyak 95 siswa, kelas 2 sebanyak 82 siswa dan kelas 3 sebanyak 80 siswa.

C. Teknik pengumpulan data

Pada penelitian ini pengumpulan data dilakukan dengan cara memberikan kuesioner pada responden. Pengumpulan data di SMU Negeri 1 Kutalimbaru dengan meminta kesediaan siswa untuk mengisi kuesioner.

\section{Instrumen penelitian}

Indtrumen penelitian yang dunakan dalam peneloitian ini adalah kuesioner tertutup yang disusun secara terstruktur yang berisi pertanyaan - pertannyaan yang harus diisi oleh responden. Kuesioner untuk mengukurpengetahuan yang berhubungan dengan perilaku tentang kesehatan reproduksi.

E. Pengolahan dan Analisa data

Langkah-langkah dalam analisis data meliputi :

1. Editing : mengedit kuesioner yang telah diteliti.

2. Coding : memberi kode tertentu untuk setiap pertanyaan.

3. Tabulating : data nilai dikumpulkan dan dikelompokkan secara teliti dan teratur ke dalam tabel.

4. Analiting : pengolahan data dengan menggunakan program SPSS.

\section{HASIL PENELITIAN}

\section{A. Karakteristik Responden}

Jumlah responden dalam penelitian ini adalah 90 remaja akhir (usia 15-20 tahun) yang berdomisili di desa Kutalimbaru serta masuk dalam kriteria menjadi responden. Karakteristik responden pada penelitian ini meliputi : jenis kelamin, yang tidak ditampilkan dalam tabel berikut ini 
Tabel 1. Distribusi Frekuensi Jenis Kelamin Responden di SMA Negeri I Kutalimbaru Bulan Oktober 2013

\begin{tabular}{ccc}
\hline Jenis Kelamin & $\begin{array}{c}\text { Frekuensi } \\
(\mathrm{n})\end{array}$ & $\begin{array}{l}\text { Persentase } \\
(\%)\end{array}$ \\
\hline Laki-laki & 96 & 37,3 \\
Perempuan & 161 & 62,7 \\
Total & 257 & 100 \\
\hline
\end{tabular}

Berdasarkan tabel 1 tersebut, dapat diketahui bahwa paling sedikit responden dalam penelitian ini adalah laki - laki yaitu sebanyak 96 responden (37,3\%). Hal ini menunjukkan bahwa sedikit sekali responden mempunyai karakter yang lebih mudah terangsang dan tertarik pada persoalan seksualitas, dan secara tidak langsung mendorongnya untuk lebih permissive dalam berperilaku seksuai

B. Faktor - faktor Yang Mempengaruhi Perilaku Seksual Remaja

1. Pengetahuan Tentang Kesehatan Reproduksi Dari analisis data untuk tingkat pengetahuan kesehatan reproduksi didapatkan skor minimum 5 dan skor maksimumnya 34 .

Berdasarkan hasil tersebut maka pengetahuan remaja dikategorikan menjadi tiga jenjang, yaitu tingkat pengetahuan kurang, cukup dan baik. Pengetahuan baik $=76-100 \%$, cukup $=56-75 \%$ dan kurang $<56 \%$. Dengan batasan tersebut maka hasil pengukuran tingkat pengetahuan meliputi pengetahuan baik adalah yang terbesar yaitu sebanyak 134 responden (52\%), pengetahuan kurang adalah yang terkecil yaitu sebanyak 23 responden (9\%) dan pengetahuan cukup sejumlah 35 responden (39\%).

2. Perilaku Seksual

Distribusi perilaku seksual ditentukan oleh jumlah skor dari setiap item pertanyaan yang telah ditentukan sebelumnya. Dari hasil analisis data dapat dikemukakan skor minimum $=0$ dan skor maksimum $=7$. Berdasarkan hasil tersebut maka perilaku seksual remaja dikategorikan menjadi tiga jenjang yaitu perilaku kurang baik,cukup baik, dan baik. Perilaku baik $=76-100 \%$, cukup 56-75 \% dan kurang $<56 \%$. Dengan batasan tersebut maka hasil pengukuran perilaku seksual remaja di SMA Negeri 1 Kutalimbaru adalah sebagian besar remajanya berperilaku seksual baik yaitu sebanyak 164 responden (64\%), yang berperilaku kurang baik sebanyak 67 responden ( $26 \%$ ), dan yang berperilaku cukup baik sebanyak 26 responden (10\%). Ini berarti bahwa rata-rata responden penelitian memiliki perilaku seksual yang baik. Hal tersebut disebabkan oleh adanya pengetahuan yang baik khususnya tentang kesehatan reproduksi dan penyebaran rangsangan seksual di daerah penelitian masih tergolong sedang, serta sudah ada kegiatan Kesehatan Reproduksi Remaja (KRR) yang dilakukan puskesmas Kutalimbaru secara rutin ke sekolahsekolah termasuk SMA negri I Kutalimbaru sehingga remaja di daerah tersebut rata-rata memiliki perilaku seksual yang Data mengenai distribusi frekuensi perilaku seksual responden

Tabel 2. Disrtibusi Frekuensi Perilaku Seksual Remaja Di SMU Negeri 1 Kutalimbaru Oktober 2013

\begin{tabular}{lll}
\hline $\begin{array}{l}\text { Kategori Perilaku } \\
\text { Seksual }\end{array}$ & $\begin{array}{c}\text { Frekuensi } \\
(\mathrm{n})\end{array}$ & $\begin{array}{c}\text { Persentase } \\
(\%)\end{array}$ \\
\hline Kurang & 26 & 10 \\
Cukup & 67 & 26 \\
Baik & 164 & 64 \\
\hline Total & 257 & 100 \\
\hline
\end{tabular}

C. Hasil Analisis Regresi Sederhana Pengetahuan Kesehatan Reproduksi Mempengaruhi Perilaku Seksual Remaja Berdasarkan pengujian regresi sederhana pada tabel 10, menunjukkan hasil bahwa nilai $t$ hitung $>$ tabel $(2,699>2,000)$ sehingga Ho ditolak atau Ha diterima. Jadi ada pengaruh antara faktor pengetahuan tentang kesehatan reproduksi terhadap perilaku seksual. Nilai R square (R2) sebesar 0,076, hal ini berarti bahwa 7,6 \% dari perilaku seksual remaja bisa dijelaskan oleh variabel pengetahuan tentang kesehatan reproduksi, sedangkan 92,4\% sisanya dijelaskan oleh variabel di luar model. Hasil pengujian tersebut jug didukung dengan nilai probabilitas (Sig.) $=0,008$ lebih kecil daripada tingkat signifikansi yang telah ditentukan, yaitu $\square=0,05$. Nilai probabilitas (Sig.) $=0,008$ berarti Ha diterima atau ada pengaruh antara faktor pengetahuan tentang kesehatan reproduksi terhadap perilaku seksual remaja.

Tabel 3. Pengujian Regresi Sederhana antara Faktor Pengetahuan Kesehatan Reproduksi terhadap Perilaku Seksual Remaja di SMU Negeri I Kutalimbaru

\begin{tabular}{|c|c|c|c|c|}
\hline Variabel & B & Nilai t & Signifikansi & $\begin{array}{c}\mathrm{R} \\
\text { square }\end{array}$ \\
\hline $\begin{array}{l}\text { Faktor pengetahuan } \\
\text { kesehatan reproduksi }\end{array}$ & 0,097 & 2,699 & 0,008 & 0,076 \\
\hline
\end{tabular}

Sebagian besar responden dalam penelitian memiliki pengetahuan tentang kesehatan reproduksi yang tergolong baik yaitu sebanyak 47 responden $(52,2 \%)$.

Seperti diungkapkan oleh Handayani (2011) dalam penelitiannya, bahwa adanya pengetahuan tentang manfaat sesuatu hal dapat mempengaruhi niat untuk ikut dalam suatu kegiatan. Sehingga semakin baik pengetahuan responden tentang kesehatan reproduksi maka akan semakin baik pula perilaku seksualnya.

Hal ini sesuai dengan yang diungkapkan oleh Ancok bahwa antara pengetahuan dan perilaku sangat berkaitan erat. Pengetahuan bermanfaat dan akibat buruk sesuatu hal akan membentuk sikap, kemudian dari sikap itu akan muncul niat.

Niat yang selanjutnya akan menentukan apakah kegiatan akan dilakukan atau tidak. Sehingga semakin baik pengetahuan tentang kesehatan reproduksi maka semakin baik perilaku seksualnya (Anggraeni, 2011).

Pengetahuan merupakan hasil tahu, dan ini terjadi setelah orang melakukan penginderaan terhadap suatu objek tertentu. Penginderaan terjadi melalui panca 
indera manusia, yaitu indera penglihatan, pendengaran, penciuman, rasa dan raba.

Sebagian besar pengetahuan manusia diperoleh melalui mata dan telinga. Dan diperkuat oleh teori Green bahwa pengetahuan merupakan faktor predisposisi menentukan terbentuknya perilaku seseorang. Pengetahuan merupakan domain yang sangat penting dalam membentuk perilaku seseorang. Dari pengalaman dan penelitian terbukti bahwa perilaku yang didasari oleh pengetahuan akan lebih baik dari pada perilaku yang tidak didasari oleh pengetahuan. (Notoadmodjo, 2003).

\section{KESIMPULAN}

Dari penelitian ini dapat diambil kesimpulan remaja akhir (usia 15 - 20 tahun) di SMU Negeri 1 Kutalimbaru rata-rata mempunyai pengetahuan tentang kesehatan reproduksi yang baik. Faktor pengetahuan tentang kesehatan reproduksi memberikan pengaruh terhadap perilaku seksual remaja di SMU Negeri Kutalimbaru

\section{DAFTAR PUSTAKA}

Ali, M. dan Asrori, M. (2004) Psikologi Remaja Perkembangan Peserta Didik.Jakarta : PT Bumi Aksara

Arikunto, S. (2005) Manajemen Penelitian. Jakarta : Rineka Cipta
Arikunto, S. (2006) Prosedur Penelitian Suatu Pendekatan Praktek. Jakarta : Rineka Cipta

Azwar, S. (2004) Penyusunan Skala Psikologi. Yogyakarta: Pustaka Pelajar

Bawono, Anton (2006) Multivariate Analysis dengan SPSS. Jawa Tengah : STAIN Salatiga Press

Dariyo, A. (2004) Psikologi Perkembangan Remaja. Bandung : Ghalia Indonesia

Dianawati, A. (2004) Psikologi Seks untuk Remaja. Jakarta : Kawan Pustaka

Depertemen Kesehatan Republik Indonesia Direktorat Jendral Bina Kesehatan Masyarakat; 2008 Jakarta

Effendy,N.(1998) Dasar-dasar Keperawatan Masyarakat. Jakarta : EGC

Niken (2005) Pengetahuan dan Sikap Remaja tentang Pornografi pada Siswa-siswi di SMK Negeri 9 Surakarta. Karya Tulis Ilmiah. Yogyakarta :UGM

Notoatmodjo, S. (2003) Pendidikan dan Perilaku Kesehatan. Jakarta : Rineka Cipta

Nursalam (2007) Metodologi Penelitian Ilmu Keperawatan. Jakarta : Salemba Medika

Sarwono (2004) Psikologi Remaja. Jakarta : Raja Grafindo Persada

Soetjiningsih (2010) Tumbuh Kembang Remaja dan Permasalahannya. Jakarta : Sagung Seto

Sugiyono (2006) Statistika Untuk Penelitian. Bandung : Alfabet 